\title{
The Impact of Student Engagement Towards Computer Accounting Competence of Accounting Education Student in Indonesia
}

\author{
Damas Gianluigi Alrizqi ${ }^{1}$, Fahmi Ibnu Ibad ${ }^{1}$, Kusmuriyanto ${ }^{1}$, Muhammad Feriady ${ }^{1, *}$ \\ ${ }^{1}$ Universitas Negeri Semarang \\ *Corresponding author.Email: mferiady@mail.unnes.ac.id
}

\begin{abstract}
This study aimed to examine whether self-efficacy (SLF), self-regulated (SRG), computer attitude (CMPT), and student engagement (S.E.) were the factors forming the competency of student accounting computers (ACC). This research was also motivated by I-E-O Astin's theory with the empirical conditions that existed in the field. This study's population were accounting students of Semarang State University 2016 and 2017, as many as 200 students. The sampling technique in this study used saturated samples so that all populations were sampled. Data collection used in this study was a questionnaire. The analysis technique used was descriptive analysis and Structural Equation Model (SEM) analysis using AMOS 23. Descriptive analysis results showed that computer accounting competencies, self-efficacy, self-regulation, computer attitude, and student engagement had good data dissemination representations. Furthermore, the study results showed that self-efficacy and self-regulated did not affect computer accounting competencies. Selfefficacy did not affect student engagement. Then self-efficacy and self-regulated did not influence computer accounting competence through student engagement. Computer attitude affected the competence of computer accounting. Selfregulated, computer attitude and student engagement influenced the competence of computer accounting. Computer attitude had an influence on computer accounting competence through student engagement.
\end{abstract}

Keywords: Student Engagement, Accounting Computer, Competencies, Computer Attitude, Self-regulated

\section{INTRODUCTION}

Accountants are one of the professions that are directly involved in it which of course has a disruptive impact on how an accountant carries out his profession, besides having to adapt by increasing self-capability and accountant performance to increase knowledge and progress in the use of digital technology in facing the industrial revolution 4.0 which already initiated. Gerd Leonhard [9] predicts that globally, the digital industrial era will eliminate 1-1.5 million jobs from 2015 to 2025 due to human factors replaced by machines. The technology contributes to eliminating 800,000 jobs in the U.K. alone. Implementation of industry 4.0 with the start of socialization to make the national plan to prepare H.R. competencies and digital infrastructure. Therefore, the accountant profession must develop computer accounting competencies in responding to the era of disruption 4.0, especially for students who are taking the accounting profession in higher education institutions.
Given the importance of mastering digital technology in the era of disruption or the era of 4.0, computer accounting competencies must be considered by the accounting profession. The accounting computer is a program designed to make it easier to do accounting done manually in preparing financial reports [18]. Computer accounting competence is an ability that a person must have after completing learning.

Computer accounting learning can be examined from three educational constructs: input, environment, and outcome (I-E-O) [2]. Information includes student demographics, background, and previous experiences. The ground or environment includes various experiences encountered during learning activities. The setting is measured by student engagement, which is a proxy for the learning process. While the outcome or results in the form of character, knowledge, attitudes beliefs, values that exist after taking the learning process understanding of accounting information systems.[6]. 
Astin's development model emphasizes student involvement as an input or input in an educational environment. The I-E-O model is adjusted to explain the relationship between student input and the academic environment [14]. Another study by [11] reveals that using the Astin I-E-O model can be seen as the influence of the learning environment on the outcome an educational institution wants to achieve. Therefore, researchers used the I-E-O model to determine the factors that affect computer accounting competence.

Computer accounting competence is an expected outcome in higher education. Referring to the Astin model in this study, environmental variables and student input factors for computer accounting competence will be proxied. Environment variables will be measured using student involvement in accessing learning facilities and learning at the University [26].

Several researchers who are in line with [20], [24], [11], [8] states that psychological factors or factors from within a person often affect outcomes in learning activities. Therefore, researchers want to make psychological factors in measuring computer accounting competence.

Self-efficacy is a psychological factor that affects accounting competence. According to [10] state that selfefficacy is a person's belief in performing a task. This is evidenced by [19] and (2014) self-efficacy affects learning outcomes. Contrary to [22] and (2018), selfefficacy does not affect student achievement.

Besides that, self-regulated is also one of the factors that influence accounting competence. This selfregulated learning is evidenced by the research conducted by [4] in their research which shows the results that selfregulated learning affects learning achievement. However, [22] show different results: self-regulation does not affect learning achievement.

Another factor that affects computer accounting competence is computer attitude. [14] said computer attitude is a person's computer attitude in operating a computer that can affect the user's expertise. This is evidenced by [12], who state that computer attitude affects learning understanding of accounting information systems. However, this statement was refuted by the idea of [16], which stated the opposite where computer attitude has no significant effect on student mastery and skills in operating computers. In connection with this problem, researchers are interested in examining this phenomenon using the Astin I-E-O model.

Based on this background, this study will propose a theoretical model development of Astin's theory and its application in the world of higher education. The Astin Input - Environment - Outcome model will be developed by making computer accounting competencies the outcome of Higher Education by including several input and environmental factors that determine the outcome.
The study entitled "Determinants of computer accounting competencies in UNNES Accounting Education Students in terms of using Astin's I-E-O theory" is expected to be able to contribute to Astin's theory and its application in higher education.

\section{RESEARCH METHOD}

This research is a type of quantitative research involving 200 students as research respondents. The data analysis technique uses structural equation modelling or SEM, with the following equation:

(1) $\mathrm{SE}=\beta_{1} \mathrm{SLF}+\beta_{2} \mathrm{SRG}+\beta_{3} \mathrm{CPMT}+\mathrm{e}_{1}$

(2) $\mathrm{AAC}=\beta_{1} \mathrm{SLF}+\beta_{2} \mathrm{SRG}+\beta_{3} \mathrm{CPMT}+\beta 4 \mathrm{SE}+\mathrm{e}_{2}$

Information:

SLF: Self-Efficacy

SRG: Self-Regulated

CMPT: Computer Attitude

SE.: Student Engagement

ACC: Accounting computer competence $\varepsilon$ : error

The equation is arranged based on the research hypothesis built in this study, namely:

H1: Self-efficacy affects student engagement

$\mathrm{H} 2$ : Self-regulated affects student engagement

H3: Computer attitude affects student engagement

H4: Self-efficacy affects computer accounting competence

H5: Self-regulated influence on accounting computer competence

H6: Computer attitude affects computer accounting competence

H7: Student engagement affects accounting competence

\section{RESULTS AND DISCUSSION}

The first stage in structural analysis is to analyse the quality of the model built in the study. The results of the model analysis can be seen in table 1 .

Based on table 1, it can be seen that almost all of the prerequisites for testing the model are met. This indicates that the model built in this study is by the conceptual model building in Astin theory. These results are in line with research conducted by [13], (2010), and [11], which state that in an educational construct, environmental influences and individual characteristics are the dominant factors.

Table 1: Results of the model analysis

\begin{tabular}{|l|l|l|}
\hline \multicolumn{1}{|c|}{ Fit indicate } & \multicolumn{1}{c|}{ Criteria } & \multicolumn{1}{c|}{ Model } \\
\hline$\chi 2$ Chi Square & Expected Low & 194,127 \\
\hline CMIN/DF & $\leq 2.00$ & 1,085 \\
\hline GFI & $\geq 0.90$ & 0,907 \\
\hline
\end{tabular}




\begin{tabular}{|l|l|l|}
\hline RMSEA & $\leq 0.08$ & 0,022 \\
\hline AGFI & $\geq 0.90$ & 0,881 \\
\hline TLI & $\geq 0.90$ & 0,990 \\
\hline CFI & $\geq 0.90$ & 0,991 \\
\hline $\begin{array}{l}\text { Significancy } \\
\text { Probability }\end{array}$ & $\geq 0.05$ & 0,208 \\
\hline
\end{tabular}

Source: Amos 23 output

In the next stage, SEM analysis can be used to explain the relationship between variables in the model that has been compiled. The results of this analysis can be seen in Figure 1 and Table 2.

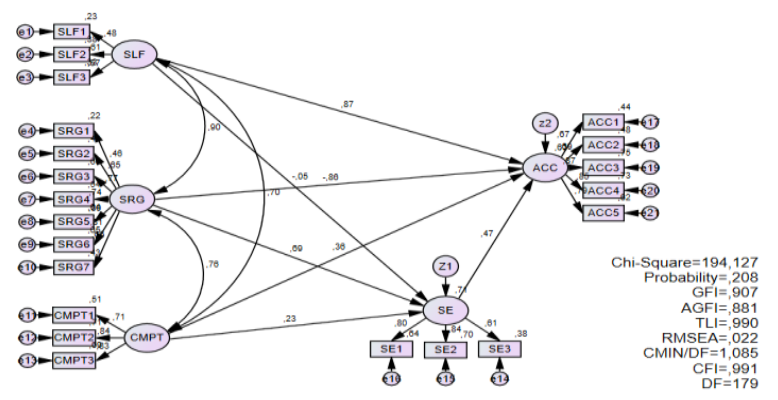

Figure 1. Relationship Between Variables in the Model

Figure 1 can be seen in detail in Table 2 as follows:

Table 2: Relationship Between Variables in Model

\begin{tabular}{|l|l|l|l|l|}
\hline & Estimate & S.E. & C.R. & P \\
\hline S.E. $\leftarrow$ SLF &,- 064 &, 439 &,- 145 &, 885 \\
\hline SE $\leftarrow$ CMPT &, 246 &, 125 & 1,972 &, 049 \\
\hline SE $\leftarrow$ SRG & 1,038 &, 478 & 2,170 &, 030 \\
\hline ACC $\leftarrow$ SRG &,- 728 &, 546 & $-1,334$ &, 182 \\
\hline ACC $\leftarrow$ S.E. &, 264 &, 131 & 2,011 &, 044 \\
\hline ACC $\leftarrow$ CPMT &, 217 &, 107 & 2,030 &, 042 \\
\hline ACC $\leftarrow$ SLF &, 697 &, 487 & 1,432 &, 152 \\
\hline
\end{tabular}

Source: Amos 23 output.

Based on Table 2, it can be seen that computer attitude affects student involvement in computer accounting practices. This can be seen from the magnitude of the probability $\mathrm{P}=0.049<0.05$. this is in line with the findings of [12]. Furthermore, the results show that there is a relationship between Self-regulated and student engagement with a probability value of 0.03 $<0.05$. These results confirm [24], which state that the better the self-regulated students will be involved in lectures so that the accounting competence of students will be useful.

This study found that the relationship between student engagement and student computer accounting competencies can be seen from the p-value $=0.044$ $<0.05$. This result is in line with the findings of [1], [27], [7], which states the importance of student engagement on educational outcomes. Furthermore, this study found a relationship between computer attitude towards computer accounting competence with a $p=0.042<0.05$.
[12] and [14], who in their research stated that there was an influence between computer attitude and learning understanding of accounting information systems, in this case, the outcome in learning.

\section{CONCLUSION}

The results of this study can be concluded that selfefficacy and self-regulated do not affect computer accounting competence. In contrast, computer attitude and student engagement affect computer accounting competence. Self-efficacy does not affect student engagement, while self-regulated and computer attitudes affect student engagement. Self-efficacy and selfregulation do not have a significant effect on computer accounting competence through student engagement. In contrast, computer attitude is having a substantial impact on computer accounting competence through student engagement.

The determining factor for computer accounting competence in this study is student engagement. This is supported by previous research and can be understood because if educational institutions' input is increasingly involved in lectures, they will understand the material being studied and produce useful computer accounting competencies.

\section{REFERENCES}

[1] Astin, A. W., Student Involvement: A Developmental Theory for Higher Education. Journal of College Student Development, 40(5), 1984, pp 518-529.

[2] Astin, A. W., Student involvement: A developmental theory for higher education. Journal of College Student Development, 40(5), 1999, pp 518-529.

[3] Butler, D. L., Cartier, S. C., Schnellert, L., Gagnon, F., \& Giammarino, M., Secondary students ' selfregulated engagement in reading: researching selfregulation as situated in context. Psychological Test and Assessment Modeling, 53(1), 2011, pp 73-105.

[4] Eva, Latipah, Strategi Self-Regulated Learning dan Prestasi Belajar: Kajian Meta Analisis. Jurnal Psikologi (Yogyakarta), 37(1), 2015, pp 110-129. https://doi.org/10.22146/jpsi.7696

[5] Ferdinand, A., Structural Equation Modelling (5th ed.). Semarang, 2014

[6] Feriady, M., \& Yanto, H., Developing Students Work Readiness Model on Accounting Program of Vocational High School (VHS) Base on I-E-O Astin Model, 2018, 77-90. https://doi.org/10.18502/kss.v3i10.3120 
[7] Hamzah, M. R. G. N. B. Z., \& Heri yanto, Kompetensi Internasional Akuntansi Forensik Mahasiswa Akuntansi Di Beberapa Universitas Di Semarang, 3(3), 2015, pp 768-785

[8] Herawaty, D., Pengaruh Kecerdasan Emosional, Partisipasi Guru Dalam Forum Ilmiah, Keyakinan Diri (Self Efficacy), Dan Motivasi Kerja Terhadap Kinerja Guru Matematika. Jurnal Review Pembelajaran Matematika, 1(1), 2016, pp 71-85. Retrieved from http://jrpm.uinsby.ac.id

[9] Leonhard, Gerd, The 7 keys future principles of digital transformation. November 2019.

[10] Martha Oktavia dan Sri Suryoko. Pengaruh Self Efficacy dan Locus of Control Terhadap Kinerja Karyawan Divisi Redaksi PT. Semarang Intermedia Pers. Efikasi Diri, Lokus Kendali, Kinerja Karyawan, 2012.

[11] Norwani, N. M., Learning Outcomes at Higher Education Institutions: To What Extent Do Institutional Environments Contribute? Journal of Human Resource and Adult Learning, 5(June), 2009, 84-94.

[12] Novi Wulandari dan Suci Rohayati, Pengaruh Computer Knowlegde, Computer Attitude, Dan Fasilitas Laboratorium Komputer Terhadap Hasil Belajar Komputer Akuntansi Siswa Kelas XI Akuntansi SMK Negeri 1 Surabaya. Jurnal Pendidikan Akuntansi, 2015, pp 1-10.

[13] Nurellah, W., \& Yanto, H. Pengaruh student engagement terhadap kompetensi operasional pada mahasiswa jurusan akuntansi,2019.

[14] Nurjanah, Y. A. S., \& Hakim, L., Pengaruh Fasilitas Laboratorium Akuntansi, Computer Knowledge, Computer Anxiety Dan Computer Attitude Terhadap Hasillbelajar Komputer Akuntansi Siswa Kelas Xi Program Keahlian Akuntansi SMK Negeri 1 Lamongan. Jurnal Pendidikan Akuntansi, 07, 77$82,2019$.

[15] Prawira, Purwa Atmaja, Psikologi Pendidikan dalam Prespektif baru. Yogykarta: Ar-Ruzz Media, 2017.

[16] Ridho Ilham Setyawan dan Syaefullah, Pengaruh Computer anxiety dan Computer Attitude terhadap Keahlian Berkomputer Mahasiswa Akuntansi, 2014.

[17] Rika Indah Amalia. Pengaruh Self Efficacy Beliefs Terhadap Prestasi Akademik Siswa SMA Kelas XI Jurusan IPS, 2018.
[18] Rini Purwati \&, \& Warsono, S., Aplikasi MYOB Untuk Perusahaan Manufaktur. Yogyakarta: Penerbit Buku Akuntansi, 2015.

[19] Rosyida, F., Utaya, S., \& Budijanto. Pengaruh Kebiasaan Belajar dan Self-Efficacy Terhadap Hasil Belajar Geografia di SMA. Jurnal Pendidikan Geografi, 2016, pp 17-28.

[20] Safitri, M. E., \& Setiyani, R., Pengaruh Motivasi Belajar, Computer Attitude Dan Fasilitas Laboratorium Akuntansi Terhadap Prestasi Belajar Komputer Akuntansi Myob. Economic Education Analysis Journal, 5(1), 2016, pp 30-43.

[21] Shofiah, V., \& Raudatussalamah. Self-Efficacy Dan Self- Regulation Sebagai Unsur Penting Dalam Pendidikan Karakter. Jurnal Penelitian Sosial Keagamaan, 17(2), 2014, pp 214-229.

[22] Sugiyana. Pengaruh Self-Regulated Learning, SelfEfficacy dan Perhatian Orangtua Terhadap Prestasi Belajar Matematika Siswa. Psikopedagogia, 4(1), 2015, pp 63-72.

[23] Tam, M., University Impact on Student Growth: A quality measure? Journal of Higher Education Policy and Management, 24(2), 2002, 211-218. https://doi.org/10.1080/1360080022000013527

[24] Wahyuni, A. E., \& Sukirman, Peran Student Engagement Dalam Memoderasi Pengaruh SelfEfficacy Dan Self-Regulated Learning Terhadap Kompetensi Akuntansi. Economic Education Analysis Journal, 7(1), 2018, pp 92-106. https://doi.org/e-ISSN 2502-356X

[25] Widyaninggar, A. A., Pengaruh Efikasi Diri dan Lokus Kendali (Locus of Control) Terhadap Prestasi Belajar Matematika. Jurnal Formatif, 4(2), 2014, pp 89-99.

[26] Yanto, H., Towards International Competence Of Indonesian Accounting Undergraduates: A Systems Approach To Identify Intercorrelates Between Constructs Of The Education Process. University Of Southern Queensland, 2012(a)

[27] Yanto, H., University of Southern Queensland Towards International Competence of Indonesian Accounting Undergraduates: A Systems Approach to Identify Inter- Education Process A Dissertation submitted by. University of Southern Queensland, 2012(b)

[28] Yanto, H., Mula, J. M., \& Kavanagh, M. H., Developing student's accounting competencies using Astin's I-E-O model: An identification of key educational inputs based on Indonesian student perspectives, 1-24, 2011(a). 